\title{
Thujone, a widely debated volatile compound: What do we know about it?
}

\author{
Éva Zámboriné Németh · Huong Thi Nguyen
}

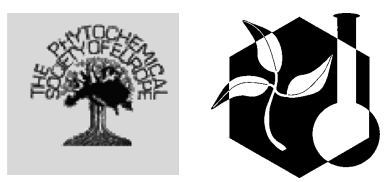

Received: 11 October 2019/Accepted: 23 March 2020/Published online: 16 April 2020

(C) The Author(s) 2020

\begin{abstract}
Thujone is a volatile monoterpene ketone of plant origin which is produced by several plants that are frequently used for flavoring foods and beverages. The use of thujone and thujone-containing plant parts for human consumption is currently regulated by the European Parliament and Council and the European Medicines Agency. The best known neurotoxic effects are connected to the GABA-gated chloride channel, where $\alpha$-thujone is a modulator roughly two to three times as potent as the $\beta$ isomer. Based primarily on in vitro experiments, genotoxicity and carcinogenic properties of thujones have also been detected in parallel with antimutagenic and immune-modulatory effects. Some of the controversial effects seem to be strongly dose-dependent. Data on antidiabetic and antimicrobial activities of thujones may show new ways to use them. This review also describes the main steps of the biosynthetic route of thujones and their occurrence in the plant kingdom. The accumulation of these compounds seems to be more abundant in some plant families (e.g. Asteraceae or Cupressaceae) than in others. Four species (Artemisia absinthium, Salvia
\end{abstract}

É. Zámboriné Németh

Department of Medicinal and Aromatic Plants, Szent István University, Villányi St. 29-35, Budapest 1118, Hungary

É. Zámboriné Németh $(\varangle) \cdot$ H. Thi Nguyen

Department of Medicinal and Aromatic Plants, Szent István University, P.O. Box 53, Budapest 1518, Hungary

e-mail: zamborine.nemeth.eva@kertk.szie.hu officinalis, Tanacetum vulgare, Thuja occidentalis), characterised by a large intraspecific chemical variability, have been evaluated in detail from chemotaxonomical aspects. Experimental results show that the phenotypic manifestation and quantity of thujones in the essential oils depend on the plant organ and its developmental phase. Besides, weather conditions and growth habitat might also influence the ratios, as well as the possibly unique responses of the individual species. Unfortunately, comparison and an exact evaluation of the references is hampered by very diverse methods of treatment and analysis; sometimes reliability itself seems questionable. In order to optimise the safe use of thujone-containing preparations, it would be necessary to do further systematic studies from the plant biological, toxicological and pharmaco-kinetic points of view.

Keywords Artemisia - Chemotype - Essential oil · Food safety $\cdot$ Salvia $\cdot$ Tanacetum $\cdot$ Toxicity $\cdot$ Thuja

$\begin{array}{ll}\text { Abbreviations } \\ \text { EMA } & \text { European Medicines Agency } \\ \text { EO } & \text { Essential oil } \\ \text { GABA } & \text { Gamma-aminobutyric acid } \\ \text { GC } & \text { Gas chromatography } \\ \text { GPP } & \text { Geranyl diphosphate } \\ \text { HMPC } & \text { Committee on Herbal Medicinal Products } \\ \text { IUPAC } & \text { International Union of Pure Applied } \\ & \text { Chemistry }\end{array}$


NADPH Nicotinamide adenine dinucleotide phosphate hydrogen

SCF Scientific Committee on Food

SS Sabinene-synthase

\section{Materials and search strategy}

This review is focused on the most characteristic facts and important up-to-date scientific information of the much debated toxic volatile monoterpene compound thujone, which might even gain pharmacologic significance in the future. Beside the human aspects, the article presents the biosynthetic route and occurrence of thujone in the plant kingdom, as well as the influencing factors of its variability. 172 published references have been cited in this review. First of all, we evaluated studies obtained from electronic databases according to a search strategy designed to retrieve abundant and new data. The review included databases such as Google Scholar, PubMed, Science Direct, SciFinder, Web of Science, etc. Additionally, other online sources (Research Gate, National Center for Biotechnology Information (NCBI), Springer Nature Open Access, Wiley Online Library, etc.) were used. In these cases no date restrictions were fixed. Besides, the bibliographies of the available publications were checked for additional references like reports, dissertations, etc. We also carried out a manual search in the Abstract books of International Symposium on Essential Oils (ISEO), International Society for Horticultural Science (ISHS) conferences, Breeding Research on Medicinal and Aromatic Plants (BREEDMAP) and Gesellschaft für Arzneipflanzenforschung (GA) in the last 10 years. Additionally, a physical search was carried out using all volumes of Journal of Essential Oil Research (JEOR) and available monographs at the library of Szent István University. The search was focused on English literature references and in some cases on German ones. The information gained from different sources was compared and evaluated to determine which facts and results have been confirmed, put into the practice, improved, extended, or even corrected.

In the present paper-if not explained otherwisethe thujone percentages mentioned refer to the ratio of this compound in the essential oil as GC area percentage.

\section{Chemical characteristics of thujone and its biosynthesis}

The monoterpene ketones, $\alpha$-thujone (3-thujone) and $\beta$-thujone (3-isothujone) (Fig. 1) are natural substances found in plants, commonly used for flavoring of foods and beverages (Lachenmeier and Uebelacker 2010). They are constituents of essential oils (EO). Their IUPAC name: (1S, 4R, 5R)-4-methyl-1-(propane-2-yl) bicyclo [3.1.0] hexan-3-one. In addition to the naturally occurring (-)- $\alpha$-thujone and $(+)-\beta$ thujones, two other enantiomeric forms are known: $(+)$ - $\alpha$-thujone and (-)- $\beta$-thujone.

Till now, the biosynthesis and genetic regulation of the thujone pathway has been studied in detail basically only in two species: Salvia officinalis (European Parliament and Council 2008) and Thuja plicata (Foster et al. 2013) both of them accumulating mainly $\alpha$-thujone. Additionally, there are some older data indicating thujone biosynthesis in tansy (Tanacetum vulgare).

The synthesis of thujone type compounds (thujane skeleton) (Fig. 2) starts from the general precursors geranyldiphosphate (GPP) (Lichtenthaler 1999) and neryl-diphosphate through a four-step biosynthetic pathway (Schilmiller et al. 2009).

The first monoterpene in this route is sabinene, the formation of which is catalyzed by the enzyme sabinene-synthase (SS). Sabinene has been demonstrated to be the precursor of thujone in A. absinthium, T. vulgare and S. officinalis (Karp and Croteau 1982).

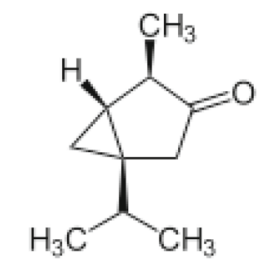

(-)- $\alpha$-thujone

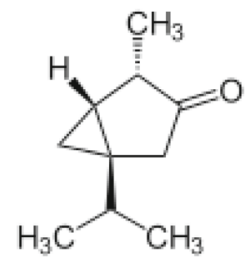

(+)- $\beta$-thujone
Fig. 1 Thujones 


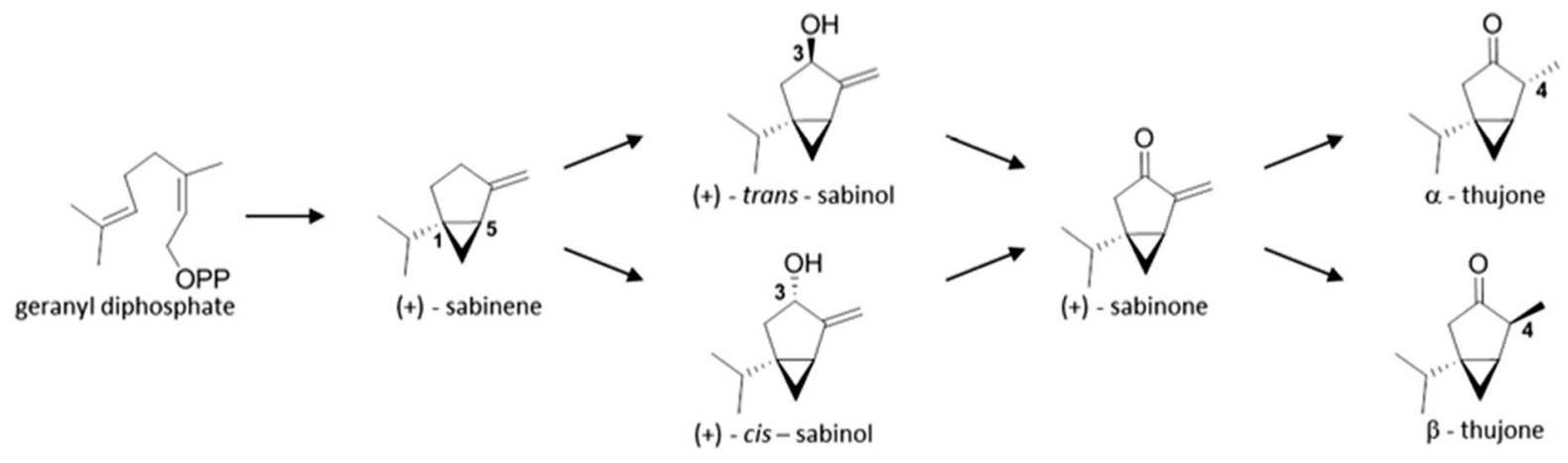

Fig. 2 Proposed biosynthesis of $\alpha$ - and $\beta$-thujones in Thuja plicata

This enzyme is considered as a 'hotspot' of chemotype evolution in sage (Grausgruber-Gröger et al. 2012). SS in Thuja plicata is supposed to be regulated by a single genomic locus (Foster et al. 2013). The latter authors proposed it as a candidate for marker-assisted selection in breeding because of its basic significance as a precursor of thujones. While the biosynthesis of other monoterpenes from the GPP precursor is frequently under transcriptional control (Schmiderer et al. 2010; Xie et al. 2008), in sage (S. officinalis) no direct correlation could be found between mRNA level and that of the sabinene end product, which reflects a more complex genetic/metabolomic regulation (Grausgruber-Gröger et al. 2012).

From sabinene, thujone is formed in three consecutive steps (Fig. 2). The next biosynthetic step leads from sabinene to either (+)-trans-sabinol in the case of gymnosperm T. plicata (Gesell et al. 2015) or (-) cis-sabinol in the angiosperm S. officinalis (Karp and Croteau 1982). Gesell et al. (2015) identified CYP750B1 and CYP76AA25 as the enzymes catalyzing the hydroxylation of (+)-sabinene to trans-sabin3 -ol. The role of the first enzyme is essential and it seems to be strongly substrate specific, while the CYP76AA25 has a broader substrate spectrum and its transcript profiles were not well correlated with thujone accumulation (Gesell et al. 2015). Earlier, Karp and Croteau (1982) suggested (-)-cis-sabinol to be the intermediary of the same pathway in sage; however, it is not known if the synthesis in Artemisia and other species is going on through trans- or cissabinol. In some manuscripts the presence of transsabinol has been demonstrated in the EO of $A$. absinthium (Blagojević et al. 2006; Judzentiene and
Budiene 2010); therefore it might be the candidate as an intermediary here.

After sabinol, only the $(+)$ isomer of sabinone is mentioned as the next intermediary in thujones' biosynthesis. Its formation is an NADPH and oxygene dependent hydroxylation. Based on investigations of sage and tansy, Dehal and Croteau (1987) suggested that dehydroxigenases exhibit a significant degree of specificity for "substrate-groups".

From sabinone, the formation of the thujones is an NADPH dependent stereoselective reduction. The corresponding enzymes of this transformation and the formation of the different isomers of thujone ( $\alpha$ - or $\beta$-thujones), has not yet been cleared up either. Based on the references, some species accumulate only one of them, while in other plants both isomers may be present (see below, "Occurence of thujone in aromatic plants, chemotaxonomic aspects" and "Intraspecific variability of thujone content in selected aromatic plants" sections).

\section{Regulatory aspects of thujone containing products}

There is an open debate on the effect of monoterpene thujone on human health. As for the potential benefits and/or harms of thujone, we should mention the special history of wormwood, which is connected to absinth, a popular strong spirit aromatised by Artemisia absinthium. At the beginning of the twentieth century, the production of absinth was prohibited in several countries as its consumption was associated with a range of severe adverse symptoms called absinthism, including convulsions, blindness, 
Table 1 Estimation of the thujone exposure via flavoring in food from Amberg-Müller (2007)

\begin{tabular}{|c|c|c|c|c|c|}
\hline \multirow[t]{2}{*}{ Foods/beverages } & \multirow[t]{2}{*}{ Proposed limit $(\mathrm{mg} / \mathrm{kg})$} & \multicolumn{2}{|c|}{ Intake $(\mu \mathrm{g} /$ person/day) } & \multicolumn{2}{|c|}{ Intake $(\mu \mathrm{g} / \mathrm{kg}$ bw/day) } \\
\hline & & Mean & 97.5th percentile & Mean & 97.5th percentile \\
\hline Sage-flavoured sausages & 10 & 175.3 & 536.6 & 2.5 & 7.7 \\
\hline Stuffing & 10 & 74.0 & 204.3 & 1.1 & 2.9 \\
\hline Herb vinegar & 5 & 12.6 & 86.9 & 0.2 & 1.1 \\
\hline Other meat dishes & 10 & 389.3 & 1148 & 5.7 & 15.3 \\
\hline "Sage Derby" cheese ${ }^{a}$ & 10 & 128.6 & 128.6 & 1.4 & 1.4 \\
\hline Salad dressings & 10 & 55 & 152 & 0.9 & 2.5 \\
\hline Vermouth & 2 & 44.2 & 177.9 & 0.7 & 2.3 \\
\hline Liqueurs and bitters & 10 & 99.7 & 474 & 1.6 & 5.9 \\
\hline Total (foods and beverages) (excl. sweets) ${ }^{\mathrm{b}}$ & & 244.8 & 911.4 & 3.6 & 13.5 \\
\hline Sweets ${ }^{\mathrm{b}}$ & 50 & 195.8 & 900.2 & 3.0 & 13.4 \\
\hline Total (foods and beverages) (incl. sweets) ${ }^{\mathrm{b}}$ & & 263.5 & 984.7 & 3.9 & 14.2 \\
\hline
\end{tabular}

${ }^{a}$ Only 1 consumer

${ }^{\mathrm{b}}$ Two intake estimates were made, including and excluding the contribution from sweets

hallucinations and mental deterioration (Lachenmeier et al. 2006a; Padosch et al. 2006). There are even some detailed cases reported in the literature from the very early times until recently. It was supposed that thujone was to blame for those cases (Weisbord et al. 1997). The study of Dettling et al. (2004) on 25 healthy subjects who consumed thujone-containing alcoholic beverages showed that the simultaneous administration of alcohol and high concentrations of thujone $(100 \mathrm{mg} / \mathrm{l})$ may severely affect attention performance.

Later, numerous investigations proved that thujone plays a minor or non-existent role in the clinical picture of absinthism (Lachenmeier et al. 2006b). According to these authors, thujone should not be the main reason for the symptoms, but adverse effects are predominantly caused by high alcohol concentration (>50 vol\%) that may lead to- and might have led to-major health and social problems, both today and in the eighteenth century. Strang et al. (1999) also suggested that acute alcohol intoxication was the main reason for the syndrome of absinthism. It could be supported in a pilot study of Kroner et al. (2005), who examined blood concentrations of both thujone and ethanol after the consumption of absinthe. They detected high blood alcohol concentrations $(>1 \mathrm{~g} / \mathrm{l})$ but-as expected-no thujone in the blood samples.

Recently, the species of Artemisia absinthium, Salvia officinalis and other thujone-containing flavoring plants are permitted in foods, because of the removal of the general limit regulation. However, according to the regulation of the European Parliament and Council (2008), thujone in chemically pure form is not allowed to be added to foods, while it may be indirectly introduced into foods by using plants containing thujone. In addition, the European Medicines Agency (EMA) also proposed a daily maximum intake of thujone in Absinthii herba, which was set at $3.0 \mathrm{mg}$ thujone/day/person as acceptable for a maximum duration of 2 weeks in the wormwood ( $A$. absinthium) monograph (EMA/HMPC 2008a). During assessments of sage (S. officinalis), a low level of thujone in sage leaf preparations is preferable, and a daily intake of $5.0 \mathrm{mg}$ thujone/day/person is acceptable for a maximum duration of 2 weeks (EMA/ HMPC 2008b). Nevertheless, some other food products (Table 1) such as sweets, salads dressings, or alcoholic drinks may contain thujone in considerable amounts (Amberg-Müller 2007).

\section{Biological activities and new ways for beneficial utilization of thujone}

Thujone-containing species are frequently used as natural remedies in ethnobotanical applications. Wormwood, as a well-known species containing thujone, has been used in folk remedies in Europe as a gynecological agent for abortion and to induce 
menstruation. Even now it is still used in Yemen to alleviate the pains associated with parturition (Rätsch 2005). According to Tan et al. (1998), wormwood has been used as traditional medicine in Asia due to its antimalarial, antiviral, antitumor, spasmolytic and other effects. Essential oil of T. occidentalis containing thujone as a major compound, has been widely used in folk medicine for the treatment of hepatoprotection, bronchial catarrh, rheumatism, psoriasis, and uterine carcinomas (Küpeli Akkol et al. 2015; Dhiman et al. 2012). In homeopathy, the extract of $T$. occidentalis containing about $65 \% \alpha$-thujone, is used as mother tincture in preparations against a number of diseases (Torres et al. 2016). Thuja preparations with thujone were regularly used by the American Indian traditional healers. The soup and the tea prepared from the inner bark of the soft twigs could relieve constipation and headache (Ellingwood 1919). It has been also used for the treatment of polyps, birthmarks, wounds, and as a painkilling and anthelmintic remedy (Pudełek et al. 2019).

Biological activities of thujone have now been justified by modern instruments, pharmacological and clinical investigations. The mechanism of neurotoxicity of thujones has been widely investigated in animals, cultured neuronal cells and expressed receptors. Thujones are modulators of the GABA-gated chloride channel where $\alpha$-thujone is about twofold to threefold more potent than $\beta$-thujone. The neuronal effect was declared to be completely reversible (Pelkonen et al. 2013). Czyzewska and Mozrzymas (2013) proved that the effect of ( $\alpha$-thujone may depend on the subtype of $\mathrm{GABA}_{\mathrm{A}}$ receptors because of their varying sensitivity. Besides, cannabinoid CB1 and serotonine 5-HB3 receptors were also suggested as potential targets of thujone. Thujones are rapidly metabolized. According to in vitro pharmacokinetic animal studies, 7-hydroxy-( $\alpha$-thujone is the main metabolite of ( $\alpha$-thujone, and 4 -hydroxy- $\beta$-thujone is that of the other isomer. In human tissues CYP2A6 seems to be the principal metabolic enzyme of thujones (Pelkonen et al. 2013). As hydroxy-thujones were detected in larger concentrations in the brain, their potential importance in the neurotoxicity has been suggested (Höld et al. 2000).

Risk assessment and setting of limit values are difficult as data originates from studies under widely varying conditions. Thujone at $25 \mathrm{mg} / \mathrm{kg}$ showed behavior changes, mortality, weight loss, decrease in the organ weight and alterations in both hepatic and renal functions of 6-8 week-old mice (Siveen and Kuttan 2011a). In single dose toxicity tests $45 \mathrm{mg} / \mathrm{kg}$ body weight was determined as the i.p. $\mathrm{LD}_{50}$ (Höld et al. 2000) and $230 \mathrm{mg} / \mathrm{kg}$ b.w. as oral $\mathrm{LD}_{50}$ value of thujones in mice (Pelkonen et al. 2013). Long term administration of sub-convulsive doses may lead to chronic toxicity. According to the latter authors, the best estimate for maximum daily intake by humans in food or herbal products is around 3-7 $\mathrm{mg} /$ day.

Beside neurotoxicity, thujones may show genotoxic and carcinogenic properties; however, antimutagenic and anticarcinogenic effects can appear, too (Nikolić et al. 2015). Most likely, these effects depend on the investigated cell type, genetic background, experimental setup and concentrations applied. A 20-h treatment of monkey Vero cells with 1-4 mM of thujone indicated antigenotoxic effects in lower dosages, but severe genotoxicity in the higher concentrations (Nikolić et al. 2011).

In coincidence with the widespread ethnobotanical application of thujone-containing drugs, in the recent period several positive physiological effects of thujone have been demonstrated. There is some data on the possible sophisticated utilizations as well. Especially interesting are the potential immuno-modulatory and antitumor activities. Recently, Küpeli Akkol et al. (2015) revealed the anti-carcinogenic potential of $\alpha$-thujone. This compound inhibited the proliferation of glioblastoma cells and angiogenesis, and in a rat model it stimulated an anticancer immune response (Torres et al. 2016). Immuno-modulatory properties of thujone have been determined by Siveen and Kuttan (2011a) on both humoral and cell mediated immune systems as well as on solid tumor development. The same authors demonstrated inhibition of melanoma metastasis by thujone in a mouse model where pulmonary metastasis was induced by B16F-10 melanoma cells in mice (20-25 g, 6- to 8-week-old males), with special emphasis on the mechanism of action (Siveen and Kuttan 2011b). An in vitro study by Biswas et al. (2011) showed the pro-apoptotic and cytotoxic effect of both the crude ethanolic extract of Thuja occidentalis and the thujone-rich fraction separated from it, on the A375 cell line. Küpeli Akkol et al. (2015) proved that the T. occidentalis essential oil and its active component, $\boldsymbol{\alpha}$-thujone demonstrate a beneficial effect in the treatment of polycystic ovary syndrome (PCOS) in a rat model. Later, Zhou et al. 
(2016) found that $\alpha$-thujone stimulates anticancer immune response. This compound enhances the proliferation of CD3AK (anti-CD3 antibody induced activated killer) cells and cytotoxicity to colon cancer cell line, especially at a dose of $0.15 \mu \mathrm{mol} / \mathrm{l}$. A recent in vitro study demonstrated promising effects of $\alpha$ thujone against glioblastoma cells whose viability and invasive potential were decreasing. In a dose-dependent manner, $\alpha$-thujone inhibited carcinoma cell proliferation and acted as a pro-apoptotic, presumably through the induction of oxidative stress in GBM cells (Pudełek et al. 2019).

Cytotoxicity $\left(\mathrm{IC}_{50}: 1.0-2.8 \mathrm{mM}\right)$ and inhibition of cell proliferation after thujone administration was also detected in other human cell lines by Nikolić et al. (2015). At the same time, low doses of thujone may activate the DNA repair mechanism and act as antigenotoxic agents.

Alkhateeb and Bonen (2010) identified the antidiabetic properties of thujone $(0.01 \mathrm{mg} / \mathrm{ml})$ in an in vitro study, showing that the compound improved insulin sensitivity in skeletal muscle. Thujone in a dosage of $5 \mathrm{mg} \mathrm{kg}^{-1}$ administered orally for 28 consecutive days was found to correct the lipid profile (cholesterol and triglycerides) in diabetic rats (Baddar et al. 2011). Sivropoulou et al. (1997) indicated that the two thujone isomers showed variable degrees of antimicrobial activity against the bacteria tested. In addition, thujones exhibited significant antiviral activity against Herpes simplex virus in vitro.

The strong antimicrobial effect of thujone compounds and thujone-containing EOs may be promising in further pharmaceutical applications (Tsiri et al. 2009). The same effect may be used for the antimicrobial decontamination of buildings (Hudson et al. 2011).

\section{Occurence of thujone in aromatic plants, chemotaxonomic aspects}

Based on references of the last 5 decades, it appears that the most frequently mentioned species concerning the thujone content of their EOs are common sage (Salvia officinalis L.), tansy (Tanacetum vulgare L.), white cedar (Thuja occidentalis L.) and wormwood (Artemisia absinthium L.). These plants belong to three different families: Lamiaceae, Asteraceae and Cupressaceae. Thus, interestingly, they do not seem to be in any special taxonomic relationship with each other. Therefore, the question arises whether the formation of thujone(s) may be considered as a chemotaxonomic marker.

The Lamiaceae family contains a lot of very popular and economically important EO producing plants, like lavender, mint, thyme, lemon balm, rosemary, oregano, basil, etc. In these genera, thujone is rarely mentioned-if at all-as an EO constituent. As for lavandin and lavender oils, thujones are basically not known and have never been reported as components above 1\% (Angioni et al. 2006; GonzálezRivera et al. 2016; Hassiotis et al. 2014; Lis Balchin 2002 etc.). In mint (Mentha) species, traces of thujone have been mentioned for several species like $M$. aquatica, M. arvensis, M. rotundifolia (Azimova and Glushenkova 2012a, b, c), M. piperita (Taherpour et al. 2017). Nevertheless, thujones are very rare in mints (Lawrence 2007; Salehi et al. 2018) and have been detected among the EO constituents in considerable concentrations only in a few exceptions, like in samples of $M$. longifolia from the Tajikistan area: $0.3-3.2 \%$ of both ( $\alpha$ and $\beta$ thujones (Sharopov et al. 2012). Ocimum species are usually free of thujone (Carović-Stanko et al. 2010; Grayer et al. 1996; Hiltunen and Holm 2006; Nurzyńska-Wierdak 2012 etc.) although in rare cases it was detected in some samples, e.g. traces $(0.36 \%)$ in an ornamental variety (Carovic-Stanko et al. 2010) or in Albanian varieties up to $6.6 \%$ (Cheliku et al. 2015). As further examples, there are no references to the presence of thujones in the EO of Melissa officinalis (e.g. SeidlerŁożykowska et al. 2017; Németh-Zámboriné et al. 2019); or Perilla frutescens (e.g. Chauhan et al. 2013; Ghimire et al. 2017; Yu et al. 1997).

On the other side, in the genus Salvia several species are characterised by thujone accumulation. It is found not only in the widely known $S$. officinalis (e.g. Craft et al. 2017; Grausgruber-Gröger et al. 2012), which is discussed here in detail later on, but in many others like $S$. fruticosa (Karousou et al. 1998), $S$. triloba (Longaray Delamare et al. 2007), S. pilifera (Kelen and Tepe 2008), etc. However, no detectable amounts or only traces of thujones were found in other species, like $S$. sclareoides (Sepahvand et al. 2014), S. aramiensis (Kelen and Tepe 2008), so it can not be established that thujones would be universal compounds of the genus Salvia. 
It should be mentioned that thujone may accumulate in some less frequently used and investigated species of the Lamiaceae family, too. For example, higher amounts were detected in Plectranthus species, where $\alpha$-thujone accumulated up to $28 \%$ of the EO (Mota et al. 2014) and in Phlomis ferruginea in 5.5\% (Formisano et al. 2006). Similarly, $\alpha$-thujone was detected by Kaurinovic et al. (2010) in $2.1-3.3 \%$ in samples of Marrubium peregrinum, nevertheless even the accumulation rate of total volatiles was very low (0.09-0.14\% DW.).

In the Asteraceae family, thujone is a frequent component of yarrow (Achillea) species. From 35 species evaluated in summary reports, 12 contained either ( $\alpha$ - or $\beta$-thujone or both in the EO, and in five species also as a major compound (Németh 2005; Kindlovits and Németh 2012; Turkmenoglu et al. 2015). At the same time, it should be mentioned that the number of studies on the individual species is varying and in several cases both thujone-containing and thujone free samples of the same species have been reported. Thus, in spite of the large number of investigations on yarrow EOs, until now the presence of thujone as a universally occurring component in any of the species can not be declared.

Similarly, in the genus Artemisia, numerous species are able to synthesize thujones. Considerable (above $20 \%$ of the EO) proportions of thujone were described in A. arborescens (Militello et al. 2012), A. herba-alba (Sbayou et al. 2014), A. pontica (Talzhanov et al. 2005), A. judaica (Saad and Abdelgaleil 2014), A. porrecta (Tétényi 1970), A. santolinifolia (Khalilov et al. 2001), A. tridentata (Tétényi 1970), and A. vulgaris (Misra and Singh 1986; Blagojević, et al. 2006). Lower concentrations were mentioned in $A$. anomala from China (Zhao et al. 2013). The distribution and ratio of the two isomers varies on a large scale and unfortunately, some older sources do not mention the isomeric form at all. The review of Abad et al. (2012) lists furthermore A. arborescens, A. distans, A. frigida, A. fukudo, A. kulbadica, A. lavandulaefolia, A. pontica, A. scoparia, A. sieberi and A. spicigera as species containing either ( $\alpha$ - or $\beta$-thujone as a major component in the EO. At the same time they found that some accessions of the same species may accumulate other major compounds and only traces of thujones. Other references ascertain the large intraspecific variabilty of wormwood species concerning the presence of thujones among their volatiles. Both thujone- containing and thujone-free samples were detected in A. campestris from Lithuania (Judzentiene and Budiene 2014), A. molinieri from France (Masotti et al. 2003) and A. vulgaris from Lithuania (Judžentien and Buzelyte 2006). The best known species, $A$. absinthium shows an extremely high variability, too (Nguyen et al. 2018c). Thus, similar to yarrow species, the overall presence or absence of thujones in any of the wormwood species can not be established. At the same time, several representatives of the large Artemisia genus have not been investigated so far.

Thujones also appear frequently in the EO accumulating species of the genus Tanacetum, either as a major component like $\beta$-thujone (up to $82 \%$ ) in $T$. vulgare (Keskitalo et al. 2001) $\alpha$-thujone up to $70 \%$ in T. argyrophyllum (Akpulat et al. 2005) or as minor ones like $\beta$-thujone in $3.6 \%$ in Tanacetum aucheranum and ( $\alpha$-thujone in $1.1 \%$ in $T$. chiliophyllum (Salamci et al. 2007). In parallel, thujone-free species are also known in large number, among others $T$. annuиm (Greche et al. 2000) and the pharmaceutically most important species $T$. parthenium (Akpulat et al. 2005). Data on the intraspecific variability of these plants concerning EO and thujones are scarce except T. vulgare (see "Intraspecific variability of thujone content in selected aromatic plants" section).

Beside the most frequently mentioned genera and species of the Asteraceae family, thujone may appear in other taxa, too. Recent references mention e.g. $32 \%$ $\alpha$-thujone in Cotula cinerea (Ghouti et al. 2018), $51.8 \% \alpha$-thujone and $14.6 \% \beta$-thujone in Anthemis mixta (Tadrent et al. 2016), 84\% $\beta$-thujone in Senecio chrysanthemoides (Mengi et al. 1995) or $5.7 \% \alpha$ thujone may appear in some accessions of Waldheimia glabra (De et al. 2017). Characteristically, these thujone-accumulating species of the family are not closely related to each other, either botanically or geographically.

Among gymnosperms, the Cupressaceae family consists of several species accumulating volatiles especially in genera Cupressus, Juniperus, and Thuja. However, concerning their thujone-producing potential, these taxa are rather different. In the genus Cupressus, thujone has not been identified in any of the following species which were subjects of phytochemical investigations: C. arizonica (Ali et al. 2013), C. atlantica, C. chengiana, C. doclouxiana, C. guadalupensis, C. macnabiana, C. sachmeriana (Pierre-Leandri et al. 2003), C. tonkinensis (Thai 
et al. 2013), C. torulosa (Padalia et al. 2013), $C$. funebris (Carroll et al. 2011; Pierre-Leandri et al. 2003), and C. sempervirens (Mazari et al. 2010; Ulukanli et al. 2014).

In terms of our study, the genus Juniperus presents a much larger intrageneric and intraspecific variability. In numerous species, like J. chinensis (Carroll et al. 2011), J. communis (Carroll et al. 2011; Lohani et al. 2010), J. excelsa (Unlu et al. 2008), J. phoenicea L. (Mazari et al. 2010) or J. saltuaria (Wedge et al. 2009), J. virginiana (Chelsey et al. 2015), and $J$. scopulorum (Zheljazkov et al. 2013) thujones either appear at most in traces, or not at all. Based on the reports, J. foetidissima shows a large intraspecific variability as both $\alpha$ - or $\beta$-thujone may be present as main compounds, but depending on the origin there are also accessions free of thujones (Tunalier et al. 2002) or accumulating only traces of them (Asili et al. 2010). Similarly, samples of the Chinese J. squamata var. fargesii may contain $\beta$-thujone in a high propotion (Adams et al. 1996) or being free of it entirely (Wedge et al. 2009). Only $1.1 \%$ thujone was detected in $J$. indica by Lohani et al. (2010), while $25 \% \beta$-thujone was the main compound of the same species in the analysis of Adams and Chaudhary (1996). As comparison studies show, there does not seem to be a clear connection between the EO composition and the origin of the samples: J. cedrus from the Canary Islands, J. brevifolia from the Azores, J. communis from Eastern Europe, J. conferta from Japan, $J$. formosana and $J$. navicularis from Portugal, $J$. oblonga (from Albania, Turkey and Iran), and $J$. oxycedrus from Asia were all free of thujones (Adams 1998). Interestingly, the biosynthetic precursor of the thujones, sabinene, appears frequently as a main constituent in Cupressus and Juniperus EOs (Padalia et al. 2013; Pierre-Leandri et al. 2003; Zheljazkov et al. 2013).

Similarly, the genus Thuja seems to exhibit a wide diversity in its EO composition. According to Tsiri et al. (2009) the major component of both T. occidentalis and T. plicata was $\alpha$-thujone (30-77\%), with considerable concentrations of $\beta$-thujone (2-9\%); although characteristic differences were registered among cultivars of both species. On the other hand, leaves of $T$. orientalis L. (syn. Biota orientalis (L.) Endl. or Platycladus orientalis (L.) Franco) either from the Himalaya (Guleria et al. 2008) or from Syria (Khubeiz et al. 2016) as well as cones of the same species from Nigeria (Ololade et al. 2014) each provided a thujone-free oil, although in a sample from London thujones were described as major components (Banthorpe et al. 1973). Data on the volatiles of the other Thuja species are spotty. The Japanese Thuja standishii may contain a small amount (1-2\%) of thujone (Banthorpe et al. 1973) while the endangered Chinese Thuja sutchuenensis produces thujone-free oil (Lei et al. 2010).

In Cupressaceae, thujone is not exclusively synthesized in the above mentioned plant families, but appears in other taxa, too. In addition to this family, Gildemeister and Hoffmann (1963) listed others, such as Pinaceae (genus: Tsuga), Rutaceae (genus: Boronia), and Verbenaceae (genera: Aloysia, Acantholippia) as accumulating thujones in the EOs.

\section{Intraspecific variability of thujone content in selected aromatic plants}

According to the available references, the content of thujone compounds in EOs displays a significant intraspecific variation even in the most well known thujone accumulating species like garden sage, white cedar, tansy and wormwood. This variation might be due to several factors such as genetic potential, ontogenetic factors, plant organs or environmental effects- as demonstrated in the next section. Table 2 summarizes the information of the thujone isomers regarding their presence and concentration in EOs of these most common thujone containing species. It should be mentioned that the sampling, the analytical methods and quantification are different in many cases, therefore most of the data basically represent ages and intervals in comparison.

It can be established that one of the isoforms usually dominates, and its presence seems to be a characteristic of the species. While sage and white cedar generally contain more $\alpha$-thujone, tansy and wormwood usually contain more $\beta$-thujone, although contradictory examples can also be found. The occurrence of either of the isomers without detection of at least traces of the other one has been very rarely published in these species (e.g. wormwood: Judzetiene and Budiene 2010 or tansy: Goudarzi et al. 2015).

A review of Nguyen and Németh (2016) has summarized the concentrations of thujones in $A$. absinthium oils, which ranged between 36.8 and 
Table 2 Intraspecific variability of thujone content in four characteristic thujone containing species

\begin{tabular}{|c|c|c|c|c|c|}
\hline Species & $\begin{array}{l}\text { Plant } \\
\text { part }\end{array}$ & $\begin{array}{l}\alpha \text {-Thujone (per cent of } \\
\text { GC area) }\end{array}$ & $\begin{array}{l}\beta \text {-Thujone (per cent of } \\
\text { GC area) }\end{array}$ & $\begin{array}{l}\text { Origin of } \\
\text { sample }\end{array}$ & Reference \\
\hline \multirow{17}{*}{$\begin{array}{l}\text { Artemisia } \\
\text { absinthium }\end{array}$} & $\mathrm{L}$ & $23.0-25.4$ & $49.5-66.8$ & Belgium & Nguyen et al. (2019) \\
\hline & $\mathrm{F}$ & $15.9-24.5$ & $51.5-60.9$ & Belgium & Nguyen et al. (2019) \\
\hline & $\mathrm{AP}$ & 0.5 & 10.1 & Canada & Lopes-Lutz et al. (2008) \\
\hline & $\mathrm{L}$ & $1.1-2.5$ & $20.9-48.6$ & Croatia & Juteau et al. (2003) \\
\hline & $\mathrm{L} \& \mathrm{~F}$ & $0.2-1.8$ & $14.0-43.2$ & Croatia & Juteau et al. (2003) \\
\hline & $\mathrm{AP}$ & 2.4 & 64.6 & Estonia & Orav et al. (2006) \\
\hline & $\mathrm{AP}$ & $1.0-1.8$ & $2.1-85.2$ & Germany & Nguyen et al. (2018c) \\
\hline & $\mathrm{AP}$ & 4.5 & 38.7 & Greece & Orav et al. (2006) \\
\hline & $\mathrm{AP}$ & 2.2 & 40.6 & Italy & Orav et al. (2006) \\
\hline & AP & 0.9 & 18.6 & Iran & $\begin{array}{l}\text { Rezaeinodehi and Khangholi } \\
\text { (2008) }\end{array}$ \\
\hline & $\mathrm{AP}$ & $3.2-23.5$ & tr. -30.7 & Lithuania & Deiml et al. (2004) \\
\hline & AP & tr. -36.8 & tr. -48.9 & Lithuania & $\begin{array}{l}\text { Judzentiene and Budiene } \\
\text { (2010) }\end{array}$ \\
\hline & $\mathrm{L}$ & 39.7 & 7.3 & Morocco & Derwich et al. (2009) \\
\hline & $\mathrm{AP}$ & 20.8 & 13.7 & Russia & Khalilov et al. (2001) \\
\hline & $\mathrm{AP}$ & 12.7 & 7.6 & Siberia & Orav et al. (2006) \\
\hline & $\mathrm{AP}$ & 3.4 & 33.1 & USA & Tucker et al. (1993) \\
\hline & $\mathrm{L} \& \mathrm{~F}$ & 0.9 & 69.9 & USA & Nin et al. (1995) \\
\hline \multirow[t]{18}{*}{ Salvia officinalis } & $\mathrm{L}$ & 40.9 & 5.6 & Brazil & Porte et al. (2013) \\
\hline & $\mathrm{F}$ & 39.0 & 4.0 & Canada & Perry et al. (1999) \\
\hline & $\mathrm{F}$ & 37.0 & 3.0 & Denmark & Perry et al. (1999) \\
\hline & $\mathrm{AP}$ & 22.8 & 9.9 & Egypt & Ahl et al. (2015) \\
\hline & $\mathrm{F}$ & 32.0 & 8.0 & Germany & Perry et al. (1999) \\
\hline & $\mathrm{F}$ & 11.0 & 11.0 & Hungary & Perry et al. (1999) \\
\hline & $\mathrm{L}$ & $16.7-24.7$ & $4.4-8.6$ & Hungary & Nguyen et al. (2019) \\
\hline & $\mathrm{F}$ & $9.8-14.2$ & $2.9-3.4$ & Hungary & Nguyen et al. (2019) \\
\hline & $\mathrm{F}$ & 39.0 & 4.0 & Italy & Perry et al. (1999) \\
\hline & $\mathrm{AP}$ & $9.1-25.1$ & $1.1-5.0$ & Iran & Mirjalili et al. (2006) \\
\hline & $\mathrm{AP}$ & $1.2-3.7$ & $0.1-9.9$ & Jordan & Abu-Darwish et al. (2013) \\
\hline & $\mathrm{L}$ & 41.0 & 3.0 & New Zealand & Perry et al. (1999) \\
\hline & $\mathrm{AP}$ & $10.3-49.7$ & $1.5-44.9$ & Serbia & Jug-Dujaković et al. (2012) \\
\hline & AP & 28.2 & 5.1 & Serbia & Radulović et al. (2017) \\
\hline & $\mathrm{AP}$ & $22.8-41.7$ & $6.1-15.6$ & Spain & Cutillas et al. (2017) \\
\hline & $\mathrm{F}$ & 7.0 & 17.0 & Switzerland & Perry et al. (1999) \\
\hline & AP & $15.7-25.2$ & $5.3-7.1$ & Tunisia & Ben Farhat et al. (2016) \\
\hline & $\mathrm{L}$ & 21.4 & 3.9 & Tunisia & El Euch et al. (2019) \\
\hline \multirow{4}{*}{$\begin{array}{l}\text { Thuja } \\
\text { occidentalis }\end{array}$} & $\mathrm{L}$ & $38.4-64.4$ & $2.9-10.7$ & Poland & Lis et al. (2016) \\
\hline & $\mathrm{L}$ & $30.4-40.5$ & $6.5-9.0$ & Slovakia & Svajdlenka et al. (1999) \\
\hline & $\mathrm{L}$ & 49.75 & 3.14 & Turkey & Küpeli Akkol et al. (2015) \\
\hline & $\mathrm{L}$ & $39.0-56.0$ & $7.2-9.0$ & USA & Kamdem et al. (1993) \\
\hline
\end{tabular}


Table 2 continued

\begin{tabular}{|c|c|c|c|c|c|}
\hline Species & $\begin{array}{l}\text { Plant } \\
\text { part }\end{array}$ & $\begin{array}{l}\alpha \text {-Thujone (per cent of } \\
\text { GC area) }\end{array}$ & $\begin{array}{l}\beta \text {-Thujone (per cent of } \\
\text { GC area) }\end{array}$ & $\begin{array}{l}\text { Origin of } \\
\text { sample }\end{array}$ & Reference \\
\hline \multirow{11}{*}{$\begin{array}{c}\text { Tanacetum } \\
\text { vulgare }\end{array}$} & $\mathrm{AP}$ & 0.76 & 91.7 & Argentina & Gallino (1988) \\
\hline & $\mathrm{F}$ & $0-9.3$ & $0-81.9$ & Finland & Keskitalo et al. (2001) \\
\hline & $\mathrm{AP}$ & $0.06-0.5$ & $9.9-44.0$ & Iran & Goudarzi et al. (2015) \\
\hline & $\mathrm{F}$ & 49.1 & 78.4 & Lithuania & $\begin{array}{l}\text { Judzentiene and Mockute } \\
\text { (2005) }\end{array}$ \\
\hline & $\mathrm{L}$ & 34.1 & 75.4 & Lithuania & $\begin{array}{l}\text { Judzentiene and Mockute } \\
\text { (2005) }\end{array}$ \\
\hline & $\mathrm{F}$ & $0.3-0.7$ & $55.3-76.0$ & Netherlands & Hendriks et al. (1990) \\
\hline & $\mathrm{L}$ & $0.5-0.9$ & $47.4-67.9$ & Netherlands & Hendriks et al. (1990) \\
\hline & $\mathrm{AP}$ & $0-73.5$ & $0-97.7$ & Norway & Rohloff et al. (2004) \\
\hline & $\mathrm{L}$ & $9.5-26.1$ & $2.5-16.6$ & Romania & Mureşan (2016) \\
\hline & $\mathrm{AP}$ & 0.9 & 66.6 & Serbia & Radulović et al. (2017) \\
\hline & AP & 0.9 & $1.0-9.2$ & Serbia & Stevović et al. (2011) \\
\hline
\end{tabular}

$\mathrm{AP}$, arial parts (not closely defined); F, flower; L, leaf

$39.6 \%$ ( $\alpha$-thujone) and from 10.1 to $69.9 \%$ ( $\beta$ thujone). Numerous descriptions and monographs regard thujone as the most characteristic constituent of wormwood EO (Foster et al. 2013, Meschler and Howlett 1999). However, wormwood is a chemically very diverse species concerning EO composition (Nguyen and Németh 2016). Nguyen et al. (2018c) evaluated 120 individuals of 12 accessions of wormwood of different origin and detected "pure" thujone chemotypes only in four accessions, while $72.5 \%$ of the individuals were described as free of thujones. It was established that thujone accumulation is not a universal characteristic of this species and in some populations even individual variability may exist.

Similarly, the major components of EO of $S$. officinalis are $\alpha$-thujone (varying from 1.2 to $45.8 \%$ of the oil) and $\beta$-thujone (accumulating between 1.0 and $40.1 \%$ of the oil) as summarized by Kintzios (2003). At the same time, in some samples other mono- or sesquiterpene compounds may dominate. Based on these, five major chemotypes were defined by Craft et al. (2017), including $\alpha$-thujone/camphor chemotype; $\alpha$-humulene/ $\alpha$-thujone chemotype; $\beta$-thujone/ $\alpha$-thujone/camphor chemotype; 1,8 -cineole/camphor chemotype; sclareol/ $\alpha$-thujone. Interestingly, however, there is no reference, where thujones were not present at least in lower concentrations. This is definitely different from the polychemism of wormwood.
In T. vulgare, the thujone chemotype seems to be widespread and has been reported from different regions (Gallino 1988; Németh et al. 1994; Rohloff et al. 2004). A review by Lawrence (2000) indicated that the commercial essential oils of tansy are mostly of the thujone type. Rohloff et al. (2004) demonstrated the intra-population variability where the -thujone chemotype dominated (22 out of 40 plant individuals) and two individuals rich in $\alpha$-thujone were also detected. Sorsa et al. (1968) described a south-tonorth decline in the frequency of the thujone chemotype in wild populations in Europe. Thujone was also the predominant component in the essential oil of Tanacetum vulgare with the proportions of $\alpha$ thujone (19\%) and $\beta$-thujone (58\%) (SCF 2002). However, in tansy, more than 40 chemotypes have been reported, among them many without thujones in the EO (Németh et al. 1994; Németh-Zámbori 2015).

In Thuja occidentalis, thujone is characteristically the dominant compound of the EO and even the name of the genus may be the source of the name of this compound. Although the $\alpha$ isomer is always represented in higher amounts, the $\beta$-thujone is also present (Table 2). The intraspecific chemical variability seems to be relatively low and basically quantitative, as there is no reference to any white cedar EO free of any thujones. In this respect this species is similar to sage, but different from tansy and wormwood. 


\section{The effect of biotic and environmental factors on the manifestation of chemism}

The stage of development can be a determinant for the accumulation of secondary compounds during plant life (Németh 2005). Concomitantly, the composition of the essential oil including thujone may undergo major changes. During the plant development of wormwood (A. absinthium), the ratio of both main compounds ( $\alpha$-thujone and $\beta$-thujone) reached its highest value (66.8\% and $25.4 \%$, respectively) at floral budding and decreased after the flowering stage (Nguyen et al. 2018a). The results of Nguyen et al. (2018a) are in agreement with the findings of Carnat et al. (1992), who have reported that the content of thujone decreased during the ontogenetic phases. Perry et al. (1999) have proved that the total concentration of thujones (mainly cis-thujone) in S. officinalis oils differed during the vegetative period: the thujone content of the EO decreased sharply and significantly from over $40 \%$ to $25 \%$ after the flowering stage. From Iranian sage studied by Mirjalili et al. (2006), $\alpha$ thujone $(25.1 \%)$ was a major component of ripened fruit oil collected in the last phenological stage; however, in earlier developmental phases this component was found in only 9.1-13.2\%. Ben Farhat et al. (2016) also reported that the percentages of thujone varied depending on the phenological period and reached the highest level at the fruiting stage. Nguyen et al. (2019) registered the highest level of $\alpha$-thujone accumulation in sage leaf oils at the vegetative stage and budding floral stage (23.2-24.7\%) and decreased significantly during the flowering period while in flower oils, the peak of this component was detected at the floral budding stage $(14.2 \%)$ with no significant changes after that. It seems to be a general phenomenon that the accumulation of volatile compounds reaches a peak at the earlier developmental phases, usually at the beginning of flowering, and decreases sharply after flowering and during seed ripening (Mohammadi et al. 2015; Németh et al. 2007). Decreasing ratios of $\alpha$-thujone during development in the EO of S. officinalis L. were also reported by Santos-Gomes and Fernandes-Ferreira (2001) and Shadi and Saharkhiz (2016). Similarly, in the case of tansy, Wolf et al. (2012) have reported that $\beta$-thujone (55-79\%) was the main compound found in both introduced or native tansy in North America. The highest amount of $\alpha$-thujone (44\%) was detected in
Iranian tansy in two separate stages: in the leaf rosette stage and the beginning of fruit set (Goudarzi et al. 2015). Németh et al. (1994) described a slight increase of thujone content in the shoots of tansy from $42 \%$ after sprouting out to $62 \%$ during seed ripening phase. The dynamics of volatile content in the case of thujone accumulation may also be in connection with the development of oil glands and an intensive biosynthesis of volatile molecules due to their specific roles in ecological adaptation and other physiological mechanisms of the plants (Guitton et al. 2010; Németh et al. 2001).

Based on these data, ontogenesis is an important factor concerning thujone ratio in the EO. Most frequently, the level of thujone components is highest in the first period of the shoot formation; however, the degree of change depends strongly on the species. Therefore, the timing of harvest seems to be crucial to obtaining raw material with either high or low levels of thujones.

Just as chemosyndromes of the plants may vary not only according to ontogenetic phases but also by plant parts (Németh-Zámbori 2015), the thujone content varies on a large scale, too. In wormwood, Judzentiene and Budiene (2010) determined higher ratios of thujone in flowers $(5.3-10.4 \%)$ than in leaves $(0.0-8.9 \%)$. Findings by Nguyen et al. (2019) indicated that the ratio of both thujone isomers show higher amount in leaves than in flowers in both wormwood (A. absinthium) and sage (S. officinalis). Furthermore, a study in Portugal by Santos-Gomes and Fernandes-Ferreira (2001) indicated that $\boldsymbol{\alpha}$-thujone content in the oil of stems, leaves and flowers of $S$. officinalis represented about 55, 30, and $18 \%$ of the total oil, respectively. Similarly, in S. officinalis samples collected from wild regions in China, the percentage of $\beta$-thujone in leaves (14.9\%) was higher than in flower oils with $6 \%$. Nevertheless, the ratio of $\alpha$-thujone in flowers was 3 times higher than that in the leaves ( $\mathrm{Li}$ et al. 2015). In the case of Tanacetum vulgare most data refer to a higher thujone ratio in the flowers than in the leaves. Hendriks et al. (1990) found similar thujone concentrations both from tansy leaves (47.4-67.9\%) and flowers (55.3-76.0\%). In the investigations of Judzentiene and Mockute (2005) $\beta$ thujone ratios in flower and leaf oils of tansy were found to be from 24.3 to $11.1 \%$, respectively. Similarly, earlier reports described that $\beta$-thujone in 
flowers was higher compared with leaf oil in a Dutch accession (Hendriks et al. 1990).

It can be established that the results of most studies on wormwood and sage show a higher ratio of thujone in leaves than in flowers, although contradictory findings have also been published. In the case of tansy, thujone usually was measured in higher ratios in flowers than in leaves. The differences might represent the different ecological roles of these monoterpenes for different species.

According to the references, thujone content and the actual proportion of its two isomers may vary on a large scale also depending on the region or habitat the sample originates from. $\alpha$ - and $\beta$-thujones were detected in wormwood oil in $18.6 \%$ and $23.8 \%$, respectively, in a study on collected wild Iranian plants (Rezaeinodehi and Khangholi 2008). In Serbian natural populations of the same species, $\beta$-thujone was the absolute major component, representing up to $63.4 \%$ of the total oil isolated from the aerial parts, while $\alpha$-thujone occupied only $0.4 \%$ (Blagojević et al. 2006). In sage, Perry et al. (1999) classified 3 groups of different accessions from New Zealand as having high (39-44\%), medium (22-28\%) and low (9\%) total thujone content as well as three chemotypes with different proportions of $\alpha$ - and $\beta$-thujones ( $\alpha / \beta$ 10:1, 1.5:1, and 1:10). Jug-Dujakovic et al. (2012) have examined the EO composition of 25 populations of Dalmatian sage growing in Croatia and detected three quantitative chemotypes with major compounds of $\alpha$ thujone (15.2-33.9\%) and $\beta$-thujone (3.9-37.8\%). A ratio of thujone in sage oils originating from different regions (Albania, Mexico and California) varied from 17.2 to $27.4 \%$ ( $\alpha$-thujone) and from 3.8 to $6.0 \%$ in the case of $\beta$-thujone (Craft et al. 2017). T. vulgare samples from Argentina mainly contained $\beta$-thujone (91.6\%) (Gallino 1988) but Wolf et al. (2012) also reported very high levels (55-79\%) from wild tansy plants collected in the United States. Khalilov et al. (2001) have indicated that $\alpha$-thujone (30.4-40.5\%) and $\beta$-thujone (6.5-9.0\%) were main compounds in each EO sample of Thuja occidentalis originating from four regions in Slovakia. In case of this species, from several other regions the chemical profile with the dominant $\alpha$-thujone compound was found to be similar: e.g. samples from the United States (Kamdem et al. 1993), Poland (Lis et al. 2016) and Turkey (Küpeli Akkol et al. 2015).
Unfortunately, the collection site and the origin of the sample may represent both genetic variability and inherited differences together with the eventual effects of the environment and changing phenotype due to external circumstances. Genetic and environmental effects can not be separated in these cases; therefore the real background of the above mentioned information and other findings must remain undetected.

Studies in controlled environmental conditions can reveal the primary factor influencing the content and composition of the EOs (Németh-Zámbori 2015), however these experiments are scarce. Gholami et al. (2005) reported that there were significant differences in the compositions of EOs obtained from plants grown under different conditions. Thujone in field grown wormwood oil reached its highest amount (60\% and $5.5 \%$ of $\alpha$-thujone and $\beta$-thujone respectively), followed by wormwood grown in a greenhouse with $41 \%$ of $\alpha$-thujone and $3.0 \%$ of $\beta$-thujone, respectively. Interestingly, no thujone content could be detected in the case of wormwood grown in vitro (Gholami et al. 2005). A study of wormwood by Nguyen et al. (2018b) has indicated that the different temperature and light conditions created in two climatic chambers influenced the EO composition of wormwood. $\beta$-thujone was $3.3 \%$ in the oils at lower temperature with less light intensity, while this component was absent in wormwood grown under elevated temperature and high light conditions (Nguyen et al. 2018b). Under different growth conditions, considerable quantitative changes occur in the EO composition, which may influence the quality of the drug production.

\section{Conclusion}

It can be established that the production of thujone isomers is relatively widespread among volatile accumulating species. There are some plant families (e.g. Asteraceae or Cupressaceae), and genera within them (e.g. Artemisia, Achillea, Thuja, Salvia, etc.) where the presence of thujones in several species is frequent. Nevertheless, even in many of these species, the formation of thujone is not a universal phenomenon, but a considerable chemical variability has been demonstrated with thujone-containing and thujonefree intraspecific accessions or individuals. Based on the available information, the thujone-containing taxa or intraspecific accessions do not seem to have closer 
taxonomic or geographical relationships with each other. Among the best known thujone-containing species, A. absinthium (wormwood) and T. vulgare (tansy) especially show huge intraspecific chemical diversity while $S$. officinalis (garden sage) and $T$. officinalis (white cedar) are more uniform andaccording to the available references-thujone-free samples have not been described as yet.

Therefore, the formation of thujones seems to be the result of a special biosynthetic route, a route which is active in different plant species not necessarily related to each other. Furthermore, it is interesting to observe that the indirect precursor of thujone, the compound sabinene, is one of the most widespread monoterpene compounds in the EOs of a huge number of different, nonrelated plants. The presence of thujone, therefore, might be the result of an independent co-evolution of genes acting in pathways after formation of sabinene only in a restricted number of even non-related species. As another alternative, the thujone pathway may exist in many species containing sabinene, but the expression of the corresponding genes is repressed due to different metabolomic interactions leading to the lack of thujones. The latter assumption has been concluded for the accumulation of volatile terpenoids of the Lamiaceae family and might also be a first step explanation for the intraspecific variability experienced in several species. The question for thujones is still open due to the lack of appropriate and sufficient information.

In thujone producing genotypes, the accumulation of thujone is influenced by different external and internal factors. It can be established that changes have been detected during ontogenesis, as well as differences in the thujone level between plant organs harvested at the same time. Besides, environmental conditions (temperature, light) seem to be influencing factors, too. Nevertheless, systematic studies under controlled climatic conditions are still lacking for most of the relevant species.

We should emphasize that an exact evaluation of the references is hampered by the fact that methods of sampling, EO production, and analysis are very diverse and unfortunately sometimes reliability seems to be questionable. Older references frequently did not distinguish between the two thujone isomers, either.

Further research is suggested to clarify the thujone pathway concerning genetic regulation and its metabolomic connections, including isomerisation of the thujones. This should be supplemented by studies on the presence of intermediates like sabinol, sabinone and related compounds in EOs; and additional investigations on the intraspecific variability of the thujone accumulating species. In order to regulate the content of thujone in the plant material, we need more data on the physiological role or other roles of thujone in the plants, too. Likewise, discovering and justifying further areas of human application for both thujones-and their safety considerations-are serious questions.

Acknowledgements Open access funding provided by Szent Istváin University (SZIE). This research was supported by the Ministry for Innovation and Technology within the framework of the Higher Education Institutional Excellence Program (NKFIH-1159-6/2019) in the scope of plant breeding and plant protection research of Szent István University and through the European EOHUB Project (600873-EPP-1-2018-1ESEPPKA2-KA).

\section{Compliance with ethical standards}

Conflict of interest The authors declare that they have no conflict of interest.

Open Access This article is licensed under a Creative Commons Attribution 4.0 International License, which permits use, sharing, adaptation, distribution and reproduction in any medium or format, as long as you give appropriate credit to the original author(s) and the source, provide a link to the Creative Commons licence, and indicate if changes were made. The images or other third party material in this article are included in the article's Creative Commons licence, unless indicated otherwise in a credit line to the material. If material is not included in the article's Creative Commons licence and your intended use is not permitted by statutory regulation or exceeds the permitted use, you will need to obtain permission directly from the copyright holder. To view a copy of this licence, visit http://creativecommons.org/licenses/by/4.0/.

\section{References}

Abad MJ, Bedoya LM, Apaza L, Bermejo P (2012) The Artemisia L. genus: a review of bioactive essential oils. Molecules 17:2542-2566. https://doi.org/10.3390/ molecules 17032542

Abu-Darwish MS, Cabral C, Ferreira IV et al (2013) Essential Oil of common Sage (Salvia officinalis L.) from Jordan: assessment of safety in mammalian cells and its antifungal and anti-inflammatory potential. Biomed Res Int 2013:1-9. https://doi.org/10.1155/2013/538940

Adams RP (1998) The leaf essential oils and chemotaxonomy of Juniperus sect. Juniperus. Biochem Syst Ecol 26:637-645. https://doi.org/10.1016/S0305-1978(98)00020-9 
Adams RP, Chaudhary RP (1996) Leaf essential oil of Juniperus indica Bertol from Nepal. J Essent Oil Res 8:677-680. https://doi.org/10.1080/10412905.1996.9701041

Adams RP, Zhang S-Z, Chu G (1996) Essential oil of Juniperus squamata D. Don var. fargesii Redh. and Wils. leaves from China. J Essent Oil Res 8:53-56. https://doi.org/10.1080/ 10412905.1996.9700553

Ahl HS-A, Hussein MS, Gendy ASH, Tkachenko KG (2015) Quality of Sage (Salvia officinalis L.) essential oil grown in Egypt. Int J Plant Res 1:119-123

Akpulat HA, Tepe B, Sokmen A et al (2005) Composition of the essential oils of Tanacetum argyrophyllum (C. Koch) Tvzel. var. argyrophyllum and Tanacetum parthenium (L.) Schultz Bip. (Asteraceae) from Turkey. Biochem Syst Ecol 33:511-516. https://doi.org/10.1016/j.bse.2004.10.006

Ali A, Tabanca N, Demirci B et al (2013) Composition, mosquito larvicidal, biting deterrent and antifungal activity of essential oils of different plant parts of Cupressus arizonica var. glabra ('Carolina Sapphire'). Nat Prod Commun 8:257-260. https://doi.org/10.1177/1934578X1300800232

Alkhateeb H, Bonen A (2010) Thujone, a component of medicinal herbs, rescues palmitate-induced insulin resistance in skeletal muscle. Am J Physiol Regul Integr Comp Physiol 299:R804-R812. https://doi.org/10.1152/ajpregu. 00216.2010

Amberg-Müller J (2007) Pflanzen in Lebensmitteln - Aspekte der europäischen Bewertung. 4. BfR-Forum Verbraucherschutz. http://www.bfr.bund.de/cm/343/pflanzen_in_ lebensmitteln_aspekte_der_europaeischen_bewertung. pdf. Accessed 7 Aug 2019

Angioni A, Barra A, Coroneo V et al (2006) Chemical composition, seasonal sariability, and antifungal activity of Lavandula stoechas L. ssp. stoechas essential oils from stem/leaves and flowers. J Agric Food Chem 54:4364-4370. https://doi.org/10.1021/jf0603329

Asili J, Emami SA, Rahimizadeh M et al (2010) Chemical and antimicrobial studies of Juniperus sabina L. and Juniperus foetidissima Willd. essential oils. J Essent Oil-Bear Plants 13:25-36. https://doi.org/10.1080/0972060X.2010. 10643787

Azimova SS, Glushenkova AI (2012a) Mentha aquatica L. In: Azimova SS, Glushenkova AI (eds) Lipids, lipophilic components and essential oils from plant sources. Springer, London. https://doi.org/10.1007/978-0-85729-323-7_1370

Azimova SS, Glushenkova AI (2012b) Mentha arvensis L. In: Azimova SS, Glushenkova AI (eds) Lipids, lipophilic components and essential oils from plant sources. Springer, London. https://doi.org/10.1007/978-0-85729-323-7_1372

Azimova SS, Glushenkova AI (2012c) Mentha rotundifolia (L.) Huds. In: Azimova SS, Glushenkova AI (eds) Lipids, lipophilic components and essential oils from plant sources. Springer, London. https://doi.org/10.1007/978-085729-323-7_1379

Baddar NWA-H, Aburjai TA, Taha MO, Disi AM (2011) Thujone corrects cholesterol and triglyceride profiles in diabetic rat model. Nat Prod Res 25:1180-1184. https:// doi.org/10.1080/14786419.2010.496116

Banthorpe D, Davies H, Gatford C, Williams S (1973) Monoterpene patterns in Juniperus and Thuja species. Planta Med 23:64-69. https://doi.org/10.1055/s-00281099413
Ben Farhat M, Jordán MJ, Chaouch-Hamada R et al (2016) Phenophase effects on sage (Salvia officinalis L.) yield and composition of essential oil. J Appl Res Med Aromat Plants 3:87-93. https://doi.org/10.1016/j.jarmap.2016.02.001

Biswas R, Mandal SK, Dutta S, Bhattacharyya SS, Boujedaini N, Khuda-Bukhsh AR (2011) Thujone-rich fraction of Thuja occidentalis demonstrates major anti-cancer potentials: evidences from in vitro studies on A375 cells. EvidBased Complement Altern Med 2011:1-16. https://doi.org/ 10.1093/ecam/neq042

Blagojević P, Radulović N, Palić R, Stojanović G (2006) Chemical composition of the essential oils of Serbian wildgrowing Artemisia absinthium and Artemisia vulgaris. J Agric Food Chem 54:4780-4789. https://doi.org/10. 1021/jf060123o

Carnat A-P, Madesclaire M, Chavignon O, Lamaison J-L (1992) cis-Chrysanthenol, A main component in essential oil of Artemisia absinthium L. growing in Auvergne (Massif Central), France. J Essent Oil Res 4:487-490. https://doi. org/10.1080/10412905.1992.9698115

Carović-Stanko K, Orlić S, Politeo O et al (2010) Composition and antibacterial activities of essential oils of seven $\mathrm{Oci}$ mum taxa. Food Chem 119:196-201. https://doi.org/10. 1016/j.foodchem.2009.06.010

Carroll JF, Tabanca N, Kramer M et al (2011) Essential oils of Cupressus funebris, Juniperus communis, and J. chinensis (Cupressaceae) as repellents against ticks (Acari: Ixodidae) and mosquitoes (Diptera: Culicidae) and as toxicants against mosquitoes. J Vector Ecol 36:258-268. https://doi. org/10.1111/j.1948-7134.2011.00166.x

Chauhan NK, Singh S, Zafar Haider S et al (2013) Compositional variability in volatiles from different plant organs of Perilla frutescens L. cultivated in Uttarakhand (India). J Pharm Res (Mohali, India) 6:361-363. https://doi.org/10. 1016/j.jopr.2013.03.004

Cheliku N, Cvetkovikj Karanfilova I, Stefkov G et al (2015) Essential oil composition of five Basil cultivars (Ocimum basilicum) from Albania. Chem Pharm Bull 61:11-18. https://doi.org/10.33320/maced.pharm.bull.2015.61.02. 002

Chelsey SD, Jones CD, Setzer WN (2015) Essential oil compositions of Juniperus virginiana and Pinus virginiana, two important trees in Cherokee traditional medicine. Am J Essent Oil Nat Prod 2(2):17-24

Craft JD, Satyal P, Setzer WN (2017) The chemotaxonomy of common sage (Salvia officinalis) based on the volatile constituents. Medicines (Basel) 4:47. https://doi.org/10. 3390/medicines4030047

Cutillas A-B, Carrasco A, Martinez-Gutierrez R et al (2017) Salvia officinalis L. Essential oils from Spain: determination of composition, antioxidant capacity, antienzymatic, and antimicrobial bioactivities. Chem Biodivers 14(8):1-8. https://doi.org/10.1002/cbdv.201700102

Czyzewska MM, Mozrzymas JW (2013) Monoterpene $\alpha$-thujone exerts a differential inhibitory action on $\mathrm{GABA}_{\mathrm{A}}$ receptors implicated in phasic and tonic GABAergic inhibition. Eur J Pharmacol 702:38-43. https://doi.org/10. 1016/j.ejphar.2013.01.032

De J, Lu Y, Ling L et al (2017) Essential oil composition and bioactivities of Waldheimia glabra (Asteraceae) from 
Qinghai-Tibet Plateau. Molecules. https://doi.org/10.3390/ molecules 22030460

Dehal SS, Croteau R (1987) Metabolism of monoterpenes: specificity of the dehydrogenases responsible for the biosynthesis of camphor, 3-thujone, and 3-isothujone. Arch Biochem Biophys 258:287-291

Deiml T, Haseneder R, Zieglgänsberger W et al (2004) $\alpha$ Thujone reduces 5-HT3 receptor activity by an effect on the agonist-induced desensitization. Neuropharmacology 46:192-201. https://doi.org/10.1016/j.neuropharm.2003. 09.022

Derwich E, Benziane Z, Boukir A (2009) Chemical compositions and insectisidal activity of essential oils of three plants Artemisia sp: Artemisia herba-alba, Artemisia absinthium and Artemisia pontica (Morocco). Electron J Environ Agric Food Chem 8:1202-1211

Dettling A, Grass H, Schuff A et al (2004) Absinthe: attention performance and mood under the influence of thujone. J Stud Alcohol 65:573-581

Dhiman A, Bhan M, Lal R, Dhimman B, Singla C (2012) An appraisal on pharmacognosy, phytochemistry and bioactivity of Thuja occidentalis Linn. (Cupressaceae). J Pharm Sci Innov 1:1-5

El Euch SK, Hassine DB, Cazaux S et al (2019) Salvia officinalis essential oil: chemical analysis and evaluation of anti-enzymatic and antioxidant bioactivities. S Afr J Bot 120:253-260. https://doi.org/10.1016/j.sajb.2018.07.010

Ellingwood F, Lloyd JU (1994) In: Haller JS (ed) Medical Protestants- The eclectics in American medicine, Southern Illinois University Press, Carbondale, pp 1825-1939

EMA/HMPC (2008a) Final community herbal monograph on Artemisia absinthium L., herba. EMA/HMPC/234463/ 2008

EMA/HMPC (2008b) Final community herbal monograph on Salvia officinalis L., folium. EMA/HMPC/331653/2008

European Parliament and Council (2008) Regulation (EC) No. $1334 / 2008$ of the European Parliament and of the Council of 16 December 2008 on flavourings and certain food ingredients with flavouring properties for use in and on foods and amending Council Regulation (EEC) No. 1601/91, Regulations (EC) No. 2232/96 and (EC) No. 110/2008 and Directive 2000/13/EC. Off J Eur Union L354:34-50

Formisano C, Senatore F, Bruno M, Bellone G (2006) Chemical composition and antimicrobial activity of the essential oil of Phlomis ferruginea Ten. (Lamiaceae) growing wild in Southern Italy. Flavour Fragrance J 21:848-851. https:// doi.org/10.1002/ffj.1740

Foster AJ, Hall DE, Mortimer L et al (2013) Identification of genes in Thuja plicata foliar terpenoid defenses. Plant Physiol 161:1993-2004. https://doi.org/10.1104/pp.112. 206383

Gallino M (1988) Essential oil from Tanacetum vulgare growing spontaneously in "Tierra del Fuego" (Argentina). Planta Med 54:182. https://doi.org/10.1055/s-2006962391

Gesell A, Blaukopf M, Madilao L et al (2015) The gymnosperm cytochrome P450 CYP750B1 catalyzes stereospecific monoterpene hydroxylation of $(+)$-Sabinene in Thujone biosynthesis in Western Redcedar. Plant Physiol 168:94-106. https://doi.org/10.1104/pp.15.00315
Ghimire BK, Yoo JH, Yu CY, Chung I-M (2017) GC-MS analysis of volatile compounds of Perilla frutescens Britton var. Japonica accessions: morphological and seasonal variability. Asian Pac J Trop Med 10:643-651. https://doi. org/10.1016/j.apjtm.2017.07.004

Gholami M, Azizi A, Salehi P (2005) Variations in essential oil components in cultivated and regenrated Artemisia Absinthium L. Asian J Chem 17:2229-2232

Ghouti D, Lazouni HA, Moussaoui A, Chabane Sari D (2018) Chemical profile, in vitro antibacterial and antioxidant activities of Juniperus phoenicea L. and Cotula cinerea (Del.) essential oils from Southwestern Algeria. Phytotherapie 16:S74-S83

Gildemeister E, Hoffmann F (1963) Die ätherischen Öle, Band 6, vol 75. Akademie Verlag, Berlin, p 588. https://doi.org/ 10.1002/ange.19630751229

González-Rivera J, Duce C, Falconieri D et al (2016) Coaxial microwave assisted hydrodistillation of essential oils from five different herbs (lavender, rosemary, sage, fennel seeds and clove buds): chemical composition and thermal analysis. Innov Food Sci Emerg Technol 33:308-318. https:// doi.org/10.1016/j.ifset.2015.12.011

Goudarzi T, Saharkhiz MJ, Rowshan V (2015) Ontogenetic variation of essential oil content and constituents in tansy (Tanacetum vulgare L.). J Appl Res Med Aromat Plants 2:48-53. https://doi.org/10.1016/j.jarmap.2015.03.003

Grausgruber-Gröger S, Schmiderer C, Steinborn R, Novak J (2012) Seasonal influence on gene expression of monoterpene synthases in Salvia officinalis (Lamiaceae). J Plant Physiol 169:353-359. https://doi.org/10.1016/j. jplph.2011.11.004

Grayer RJ, Kite GC, Goldstone FJ et al (1996) Infraspecific taxonomy and essential oil chemotypes in sweet basil, Ocimum basilicum. Phytochemistry 43:1033-1039

Greche H, Hajjaji N, Ismaïli-Alaoui M et al (2000) Chemical composition and antifungal properties of the essential oil of Tanacetum annuum. J Essent Oil Res 12:122-124. https:// doi.org/10.1080/10412905.2000.9712058

Guitton Y, Nicolè F, Moja S et al (2010) Lavender inflorescence: a model to study regulation of terpenes synthesis. Plant Signal Behav 5:749-751. https://doi.org/10.4161/ psb.5.6.11704

Guleria S, Kumar A, Tiku AK (2008) Chemical Composition and fungitoxic activity of essential oil of Thuja orientalis L. grown in the North-Western Himalaya. Z Naturforsch C 63:211-214. https://doi.org/10.1515/znc-2008-3-409

Hassiotis CN, Ntana F, Lazari DM et al (2014) Environmental and developmental factors affect essential oil production and quality of Lavandula angustifolia during flowering period. Ind Crops Prod 62:359-366. https://doi.org/10. 1016/j.indcrop.2014.08.048

Hendriks H, van der Elst DJD, van Putten FMS, Bos R (1990) The Essential Oil of Dutch Tansy (Tanacetum vulgare L.). J Essent Oil Res 2:155-162. https://doi.org/10.1080/ 10412905.1990.9697853

Hiltunen R, Holm Y (2006) Basil: the Genus Ocimum. CRC Press, Harwood Academic Publishers, Taylor and Francis e-Library, London and New York

Höld KM, Nilantha S, Sirisoma NS, Ikeda T, Narahashi T, Casida JE (2000) $\alpha$-Thujone (the active component of absinthe): $\gamma$-aminobutyric acid type A receptor modulation 
and metabolic detoxification. Proc Natl Acad Sci 97:3826-3831. https://doi.org/10.1073/pnas.070043297

Hudson J, Kuo M, Vimalanathan S (2011) The antimicrobial properties of Cedar leaf (Thuja plicata) oil; a safe and efficient decontamination agent for buildings. Int J Environ Res Public Health 8(12):4477-4487. https://doi.org/10. 3390/ijerph8124477

Judžentien A, Buzelytė J (2006) Chemical composition of essential oils of Artemisia vulgaris L. (mugwort) from North Lithuania. Chemija 17(1):12-15

Judzentiene A, Budiene J (2010) Compositional variation in essential oils of wild Artemisia absinthium from Lithuania. J Essent Oil-Bear Plants 13:275-285. https://doi.org/10. 1080/0972060X.2010.10643822

Judzentiene A, Budiene J (2014) Variability of Artemisia campestris L. essential oils from Lithuania. J Essent Oil Res 26:328-333. https://doi.org/10.1080/10412905.2014. 933132

Judzentiene A, Mockute D (2005) The inflorescence and leaf essential oils of Tanacetum vulgare L. var. vulgare growing wild in Lithuania. Biochem Syst Ecology 33:487-498. https://doi.org/10.1016/j.bse.2004.11.003

Jug-Dujaković M, Ristić M, Pljevljakušić D et al (2012) High diversity of indigenous populations of Dalmatian sage (Salvia officinalis L.) in essential oil composition. Chem Biodiversity 9:2309-2323. https://doi.org/10.1002/cbdv. 201200131

Juteau F, Jerkovic I, Masotti V et al (2003) Composition and antimicrobial activity of the essential oil of Artemisia absinthium from Croatia and France. Planta Med 69:158-161. https://doi.org/10.1055/s-2003-37714

Kamdem PD, Hanover JW, Gage DA (1993) Contribution to the study of the essential oil of Thuja occidentalis L.: in memory of Dr. James W. Hanover who died February 21, 1992. J Essent Oil Res 5:117-122. https://doi.org/10.1080/ 10412905.1993.9698189

Karousou R, Vokou D, Kokkini S (1998) Variation of Salvia fruticosa essential oils on the Island of Crete (Greece). Bot Acta 111:250-254. https://doi.org/10.1111/j.1438-8677. 1998.tb00705.x

Karp F, Croteau R (1982) Evidence that sabinene is an essential precursor of C(3)-oxygenated thujane monoterpenes. Arch Biochem Biophys 216:616-624

Kaurinovic B, Vlaisavljevic S, Popovic M et al (2010) Antioxidant properties of Marrubium peregrinum L. (Lamiaceae) essential oil. Molecules 15:5943-5955. https://doi.org/10.3390/molecules 15095943

Kelen M, Tepe B (2008) Chemical composition, antioxidant and antimicrobial properties of the essential oils of three Salvia species from Turkish flora. Bioresour Technol 99:4096-4104. https://doi.org/10.1016/j.biortech.2007.09. 002

Keskitalo M, Pehu E, Simon JE (2001) Variation in volatile compounds from tansy (Tanacetum vulgare L.) related to genetic and morphological differences of genotypes. Biochem Syst Ecol 29:267-285. https://doi.org/10.1016/ S0305-1978(00)00056-9

Khalilov LM, Paramonov EA, Khalilova AZ et al (2001) Identification and biological activity of volatile organic compounds emitted by plants and insects. IV. Composition of vapor isolated from certain species of Artemisia Plants.
Chem Nat Compd 37:339-342. https://doi.org/10.1023/A: 1013770501841

Khubeiz MJ, Mansour G, Zahraa B (2016) Antibacterial and phytochemical investigation of Thuja orientalis L. leaves essential oil from Syria. Int J Curr Pharm Rev Res $7: 243-247$

Kindlovits S, Németh É (2012) Sources of variability of yarrow (Achillea spp.) essential oil. Acta Aliment 41:92-103. https://doi.org/10.1556/AAlim.41.2012.Suppl.9

Kintzios SE (2003) Sage: the Genus Salvia. CRC Press, New York

Kroner LU, Padosch SA, Lachenmeier DW, Madea B (2005) Investigations on the medico-legal relevance of spirits containing thujone with special regard to toxicologicalanalytical aspects. Blutalkohol 42:263-271

Küpeli Akkol E, İlhan M, Ayşe Demirel M et al (2015) Thuja occidentalis $\mathrm{L}$. and its active compound, $\boldsymbol{\alpha}$-thujone: promising effects in the treatment of polycystic ovary syndrome without inducing osteoporosis. J Ethnopharmacol 168:25-30. https://doi.org/10.1016/j.jep.2015.03.029

Lachenmeier DW, Uebelacker M (2010) Risk assessment of thujone in foods and medicines containing sage and wormwood-evidence for a need of regulatory changes? Regul Toxicol Pharmacol 58:437-443. https://doi.org/10. 1016/j.yrtph.2010.08.012

Lachenmeier DW, Emmert J, Kuballa T, Sartor G (2006a) Thujone-cause of absinthism? Forensic Sci Int 158:1-8. https://doi.org/10.1016/j.forsciint.2005.04.010

Lachenmeier DW, Walch SG, Padosch SA, Kröner LU (2006b) Absinthe-a review. Crit Rev Food Sci Nutr 46:365-377. https://doi.org/10.1080/10408690590957322

Lawrence BM (2000) Progress in essential oils: tansy oil. Perfum Flav 25:33-47

Lawrence BM (2007) Mint: the genus Mentha. CRC Press, Boca Raton, FL

Lei H, Wang Y, Su C et al (2010) Chemical composition and antifungal activity of essential oils of Thuja Sutchuenensis, a critically endangered species endemic to China. Nat Prod Commun 5:1673-1676. https://doi.org/10.1177/ 1934578 X1000501032

Li B, Zhang C, Peng L et al (2015) Comparison of essential oil composition and phenolic acid content of selected Salvia species measured by GC-MS and HPLC methods. Ind Crops Prod 69:329-334. https://doi.org/10.1016/j.indcrop. 2015.02.047

Lichtenthaler HK (1999) The 1-deoxy-D-xylulose-5-phosphate pathway of isoprenoid biosynthesis in plants. Annu Rev Plant Physiol Plant Mol Biol 50:47-65. https://doi.org/10. 1146/annurev.arplant.50.1.47

Lis Balchin M (2002) Lavender-the genus Lavadula. CRC Press, New York

Lis A, Liszkiewicz R, Krajewska A (2016) Comparison of chemical composition of the essential oils from different parts of Thuja occidentalis L. 'Brabant' and T. occidentalis L. 'Smaragd'. Herba Pol 62:20-27. https://doi.org/10. 1515/hepo-2016-0014

Lohani H, Haider SZ, Chauhan NK, Mohan M (2010) Essential oil composition of leaves and berries of Juniperus communis and Juniperus indica from Uttarakhand Himalaya. J Med Aromat Plant Sci 32(3):119-201 
Longaray Delamare AP, Moschen-Pistorello IT, Artico L et al (2007) Antibacterial activity of the essential oils of Salvia officinalis L. and Salvia triloba L. cultivated in South Brazil. Food Chem 100:603-608. https://doi.org/10.1016/j. foodchem.2005.09.078

Lopes-Lutz D, Alviano DS, Alviano CS, Kolodziejczyk PP (2008) Screening of chemical composition, antimicrobial and antioxidant activities of Artemisia essential oils. Phytochemistry 69:1732-1738. https://doi.org/10.1016/j. phytochem.2008.02.014

Masotti V, Juteau F, Bessière JM, Viano J (2003) Seasonal and phenological variations of the essential oil from the narrow endemic species Artemisia molinieri and its biological activities. J Agric Food Chem 51:7115-7121. https://doi. org/10.1021/jf034621y

Mazari K, Bendimerad N, Bekhechi C, Fernandez X (2010) Chemical composition and antimicrobial activity of essential oils isolated from Algerian Juniperus phoenicea L. and Cupressus sempervirens L. J Med Plants Res 4(10):959-964. https://doi.org/10.5897/JMPR10.169

Mengi N, Garg SN, Agarwal SK, Mathela CS (1995) The occurrence of $\beta$-thujone and a new p-menthane derivative in Senecio chrysanthemoides leaf oil. J Essent Oil Res 7:511-514. https://doi.org/10.1080/10412905.1995. 9698575

Meschler JP, Howlett AC (1999) Thujone exhibits low affinity for cannabinoid receptors but fails to evoke cannabimimetic responses. Pharmacol Biochem Behav 62:473-480

Militello M, Carrubba A, Blázquez MA (2012) Artemisia arborescens L.: essential oil composition and effects of plant growth stage in some genotypes from Sicily. J Essent Oil Res 24:229-235. https://doi.org/10.1080/10412905. 2012.676764

Mirjalili HM, Salehi P, Sonboli A, Mohammadi Vala M (2006) Essential oil variation of Salvia officinalis aerial parts during its phenological cycle. Chem Nat Compd 42:19-23. https://doi.org/10.1007/s10600-006-0027-4

Misra LN, Singh SP (1986) $\alpha$-Thujone, the major component of the essential oil from Artemisia vulgaris growing wild in Nilgiri Hills. J Nat Prod 49:941. https://doi.org/10.1021/ np50047a038

Mohammadi A, Sani TA, Ameri AA et al (2015) Seasonal variation in the chemical composition, antioxidant activity, and total phenolic content of Artemisia absinthium essential oils. Pharmacogn Res 7:329-334. https://doi.org/10. 4103/0974-8490.158441

Mota L, Figueiredo AC, Pedro LG et al (2014) Volatile-oils composition, and bioactivity of the essential oils of Plectranthus barbatus, $P$. neochilus, and $P$. ornatus grown in Portugal. Chem Biodivers 11:719-732. https://doi.org/10. 1002/cbdv.201300161

Mureşan ML (2016) The analysis of essential oils from aerial parts of Tanacetum vulgare L. growing wild in Romania. Biharean Biol 10(1):67-68

Németh E (2005) Changes in essential oil quantity and quality influenced by ontogenetic factors. Acta Hortic. https://doi. org/10.17660/ActaHortic.2005.675.23

Németh ÉZ, Héthelyi É, Bernáth J (1994) Comparison studies on Tanacetum vulgare L. chemotypes. J Herbs Spices Med Plants 2:85-92. https://doi.org/10.1300/J044v02n02_10
Németh ÉZ, Varga E, Franke R (2001) Variabilität des ätherischen Ölgehaltes und deren Ursachen in Hyssopus officinalis L. Z für Arznei-und Gewürzpflanzen 6:29-34

Németh E, Bernáth J, Tarján G (2007) Quantitative and Qualitative Studies of Essential Oils of Hungarian Achillea Populations. J Herbs Spices Med Plants 13:57-69. https:// doi.org/10.1300/J044v13n01_05

Németh-Zámbori É (2015) Natural variability of essential oil components. In: Baser KHC, Buchbauer G (eds) Handbook of essential oils: science, technology, and applications, 2nd edn. CRC Press, New York

Németh-Zámboriné É, Seidler-Łożykowska K, Szabó K (2019) Effect of harvest date on yield and secondary compounds of lemon balm (Melissa officinalis L.). J Appl Bot Food Qual 92(2019):81-87. https://doi.org/10.5073/jabfq.2019. 092.011

Nguyen HT, Németh É (2016) Sources of variability of wormwood (Artemisia absinthium L.) essential oil. J Appl Res Med Aromat Plants 3:143-150. https://doi.org/10.1016/j. jarmap.2016.07.005

Nguyen HT, Radácsi P, Gosztola B, Németh É (2018a) Accumulation and composition of essential oil due to plant development and organs in wormwood (Artemisia absinthium L.). Ind Crops Prod 123:232-237. https://doi.org/10. 1016/j.indcrop.2018.06.076

Nguyen HT, Radácsi P, Gosztola B, Németh É (2018b) Effects of temperature and light intensity on morphological and phytochemical characters and antioxidant potential of wormwood (Artemisia absinthium L.). Biochem Syst Ecol 79:1-7. https://doi.org/10.1016/j.bse.2018.03.005

Nguyen HT, Sárosi ST, Llorens-Molina JA, Ladányi M, Németh É (2018c) Compositional variability in essential oils of twelve wormwood (Artemisia absinthium L.) accessions grown in the same environment. J Essent Oil Res. https:// doi.org/10.1080/10412905.2018.1496856

Nguyen HT, Radácsi P, Rajhárt P, Németh É (2019) Variability of thujone content in essential oil due to plant development and organs from Artemisia absinthium L. and Salvia officinalis L. J Appl Bot Food Qual 92:100-105. https:// doi.org/10.5073/jabfq.2019.092.014

Nikolić B, Mitić-Ćulafić D, Vuković-Gačić B, Knežević-Vukčević J (2011) Modulation of genotoxicity and DNA repair by plant monoterpenes camphor, eucalyptol and thujone in Escherichia coli and mammalian cells. Food Chem Toxicol 49:2035-2045. https://doi.org/10.1016/j.fct.2011.05.015

Nikolić B, Vasilijević B, Mitić-Ćulafić D, Vuković-Gačić B, Knežević-Vukćević J (2015) Comparative study of genotoxic, antigenotoxic and cytotoxic activities of monoterpenes camphor, eucalyptol and thujone in bacteria and mammalian cells. Chem Biol Interact 242:263-271. https://doi.org/10.1016/j.cbi.2015.10.012

Nin S, Arfaioli P, Bosetto M (1995) Quantitative determination of some essential oil components of selected Artemisia absinthium plants. J Essent Oil Res 7:271-277. https://doi. org/10.1080/10412905.1995.9698518

Nurzyńska-Wierdak R (2012) Sweet basil essential oil composition: relationship between cultivar, foliar feeding with nitrogen and oil content. J Essent Oil Res 24:217-227. https://doi.org/10.1080/10412905.2012.676763

Ololade ZS, Fakankun OA, Alao FO, Udi OU (2014) Phytochemical and therapeutic studies of the fruit essential oil of 
Thuja orientalis from Nigeria. Glob J Sci Front Res B Chem 14(7):96-100

Orav A, Raal A, Arak E et al (2006) Composition of the essential oil of Artemisia absinthium L. of different geographical origin. Proc Estonian Acad Sci Chem 55(3):155-165

Padalia RC, Verma RS, Chauhan A, Chanotiya CS (2013) Essential oil compositions of branchlets and cones of $\mathrm{Cu}$ pressus torulosa D. Don. J Essent Oil Res 25:251-256. https://doi.org/10.1080/10412905.2013.775677

Padosch SA, Lachenmeier DW, Kröner LU (2006) Absinthism: a fictitious 19th century syndrome with present impact. Subst Abuse Treat Prev Policy 1:14

Pelkonen O, Abass K, Wiesner J (2013) Thujone and thujonecontaining herbal medicinal and botanical products: toxicological assessment. Regul Toxicol Pharmacol 65:100-107. https://doi.org/10.1016/j.yrtph.2012.11.002

Perry NB, Anderson RE, Brennan NJ et al (1999) Essential oils from Dalmatian Sage (Salvia officinalis L.): variations among individuals, plant parts, seasons, and sites. J Agric Food Chem 47(5):2048-2054

Pierre-Leandri C, Fernandez X, Lizzani-Cuvelier L et al (2003) Chemical composition of Cupressus essential oils: volatile constituents of leaf oils from seven cultivated Cupressus Species. J Essent Oil Res 15:242-247. https://doi.org/10. 1080/10412905.2003.9712130

Porte A, Godoy RLO, Maia-Porte LH (2013) Chemical composition of sage (Salvia officinalis L.) essential oil from the Rio de Janeiro State (Brazil). Rev Bras Plant Med 15:438-441. https://doi.org/10.1590/S151605722013000300018

Pudełek M, Catapano J, Kochanowski P, Mrowiec K, JanikOlchawa N, Czyż J, Ryszawy D (2019) Therapeutic potential of monoterpene $\alpha$-thujone, the main compound of $\mathrm{T}$ Thuja occidentalis L. essential oil, against malignant glioblastoma multiforme cells in vitro. Fitoterapia 134:172-181. https://doi.org/10.1016/j.fitote.2019.02.020

Radulović NS, Genčić MS, Stojanović NM et al (2017) Toxic essential oils. Part V: Behaviour modulating and toxic properties of thujones and thujone-containing essential oils of Salvia officinalis L., Artemisia absinthium L., Thuja occidentalis $\mathrm{L}$. and Tanacetum vulgare L. Food Chem Toxicol 105:355-369. https://doi.org/10.1016/j.fct.2017. 04.044

Rätsch C (2005) The encyclopedia of psychoactive plants: ethnopharmacology and its applications. (J. Baker, Trans.). Park Street Press, South Paris, ME

Rezaeinodehi A, Khangholi S (2008) Chemical composition of the essential oil of Artemisia absinthium growing wild in Iran. Pak J Biol Sci 11:946-949. https://doi.org/10.3923/ pjbs.2008.946.949

Rohloff J, Mordal R, Dragland S (2004) Chemotypical variation of Tansy (Tanacetum vulgare L.) from 40 different locations in Norway. J Agric Food Chem 52:1742-1748. https://doi.org/10.1021/jf0352430

Saad MMG, Abdelgaleil SAM (2014) Allelopathic potential of essential oils isolated from aromatic plants on Silybum marianum L. Glob Adv Res J Agric Sci 3(9):289-297

Salamci E, Kordali S, Kotan R et al (2007) Chemical compositions, antimicrobial and herbicidal effects of essential oils isolated from Turkish Tanacetum aucheranum and Tanacetum chiliophyllum var. chiliophyllum. Biochem
Syst Ecol 35:569-581. https://doi.org/10.1016/j.bse.2007. 03.012

Salehi B, Stojanović-Radić Z, Matejić J et al (2018) Plants of genus Mentha: from farm to food factory. Plants 7:70. https://doi.org/10.3390/plants7030070

Santos-Gomes PC, Fernandes-Ferreira M (2001) Organ- and Season- dependent variation in the essential oil composition of Salvia officinalis L. cultivated at two different sites. J Agric Food Chem 49:2908-2916. https://doi.org/10. 1021/jf001102b

Sbayou H, Ababou B, Boukachabine K et al (2014) Chemical composition and antibacterial activity of Artemisia herbaalba and Mentha pulegium essential oils. J Life Sci 8:35-41

SCF (2002) Opinion of the Scientific Committee on Food on Thujone. https://ec.europa.eu/food/sites/food/files/safety/ docs/sci-com_scf_out162_en.pdf. Accessed 7 Aug 2019

Schilmiller AL, Schauvinhold I, Larson M et al (2009) Monoterpenes in the glandular trichomes of tomato are synthesized from a neryl diphosphate precursor rather than geranyl diphosphate. Proc Natl Acad Sci USA 106(26):10865-10870. https://doi.org/10.1073/pnas. 0904113106

Schmiderer C, Grausgruber-Gröger S, Grassi P et al (2010) Influence of gibberellin and daminozide on the expression of terpene synthases and on monoterpenes in common sage (Salvia officinalis). J Plant Physiol 167:779-786. https:// doi.org/10.1016/j.jplph.2009.12.009

Seidler-Łożykowska K, Zawirska-Wojtasiak R, Wojtowicz E, Bocianowski J (2017) Essential oil content and its composition in herb of lemon balm (Melissa officinalis L.) breeding strains. J Essent Oil Res 29:351-356. https://doi. org/10.1080/10412905.2016.1278407

Sepahvand R, Delfan B, Ghanbarzadeh S et al (2014) Chemical composition, antioxidant activity and antibacterial effect of essential oil of the aerial parts of Salvia sclareoides. Asian Pac J Trop Med 7:S491-S496. https://doi.org/10.1016/ S1995-7645(14)60280-7

Shadi A, Saharkhiz MJ (2016) Changes in essential oil contents and chemical compositions of Artemisia sieberi at different phenological growth stages. Anal Chem Lett 6:249-256. https://doi.org/10.1080/22297928.2016.1196608

Sharopov FS, Sulaimonova VA, Setzer WN (2012) Essential oil composition of Mentha longifolia from wild populations growing in Tajikistan. J Med Act Plants 1(2):76-84

Siveen KS, Kuttan G (2011a) Augmentation of humoral and cell mediated immune responses by Thujone. Int Immunopharmacol 11:1967-1975. https://doi.org/10. 1016/j.intimp.2011.08.006

Siveen KS, Kuttan G (2011b) Thujone inhibits lung metastasis induced by B16F-10 melanoma cells in C57BL/6 mice. Can J Physiol Pharmacol 89:691-703. https://doi.org/10. 1139/y11-067

Sivropoulou A, Nikolaou C, Papanikolaou E, Kokkini S, Lanaras T, Arsenakis M (1997) Antimicrobial, cytotoxic, and antiviral activities of Salvia fructicosa essential oil. J Agric Food Chem 45:3197-3201

Sorsa M, von Schantz M, Lokki J, Forsén K (1968) Variability of essential oil components in Chrysanthemum vulgare L. in Finland. Ann Acad Sci Fenn Ser A VI(135):1-13

Stevović S, Ćalić-Dragosavac Dušica, Mikovilović Vesna Surčinski, Zdravković-Korać Snežana, Milojević Jelena, 
Cingel Aleksandar (2011) Correlation between environment and essential oil production in medical plants. Adv Environ Biol 5:465-468

Strang J, Arnold WN, Peters T (1999) Absinthe: what's your poison?: Though absinthe is intriguing, it is alcohol in general we should worry about. BMJ: Br Med J 319:1590

Svajdlenka E, Má;rtonfi P, Tomasko I et al (1999) Essential oil composition of Thuja occidentalis L. samples from Slovakia. J Essent Oil Res 11:532-536. https://doi.org/10. 1080/10412905.1999.9701208

Tadrent W, Bachari K, Kabouche Z (2016) Comparative compositions and antibacterial activity of the essential oils of Anthemis nobilis L. and Anthemis mixta L. Int J Pharm Sci 8:457-459

Taherpour AA, Khaef S, Yari A et al (2017) Chemical composition analysis of the essential oil of Mentha piperita $\mathrm{L}$. from Kermanshah, Iran by hydrodistillation and HS/SPME methods. J Anal Sci Technol 8(11):1-6. https://doi.org/10. 1186/s40543-017-0122-0

Talzhanov NA, Sadyrbekov DT, Smagulova FM et al (2005) Components of Artemisia pontica. Chem Nat Compd 41:178-181. https://doi.org/10.1007/s10600-005-0107-x

Tan RX, Zheng WF, Tang HQ (1998) Biologically active substances from the genus Artemisia. Planta Med 64:295-302. https://doi.org/10.1055/s-2006-957438

Tétényi P (1970) Infraspecific chemical taxa of medicinal plants. Akadémiai Publ. https://doi.org/10.1002/ardp. 19703030714

Thai TH, Bazzali O, Hien NT et al (2013) Chemical composition of leaf and stem oils from Vietnamese Cupressus tonkinensis Silba. J Essent Oil Res 25:11-16. https://doi.org/10. 1080/10412905.2012.751056

Torres A, Vargas Y, Uribe D et al (2016) Pro-apoptotic and antiangiogenic properties of the $\alpha / \beta$-thujone fraction from Thuja occidentalis on glioblastoma cells. J Neuro-Oncol 128:9-19. https://doi.org/10.1007/s11060-016-2076-2

Tsiri D, Graikou K, Pobłocka-Olech L et al (2009) Chemosystematic value of the essential oil composition of Thuja species cultivated in Poland-antimicrobial activity. Molecules 14:4707-4715. https://doi.org/10.3390/ molecules 14114707

Tucker AO, Maciarello MJ, Sturtz G (1993) The Essential Oils of Artemisia 'Powis Castle' and Its Putative Parents, $A$. absinthium and A. arborescens. J Essent Oil Res 5:239-242. https://doi.org/10.1080/10412905.1993. 9698215

Tunalier Z, Kirimer N, Baser KHC (2002) The composition of essential oils from various parts of Juniperus foetidissima. Chem Nat Compd 38:43-47. https://doi.org/10.1023/A: 1015725630556

Turkmenoglu FP, Agar OT, Akaydin G, Hayran M, Demirci B (2015) Characterization of volatile compounds of eleven
Achillea species from Turkey and biological activities of essential oil and methanol extract of A. hamzaoglui Arabac1 \& Budak. Molecules 20:11432-11458. https://doi.org/10. 3390/molecules200611432

Ulukanli Z, Karabörklü S, Ates B et al (2014) Chemical composition of the essential oil from Cupressus sempervirens L. horizontalis resin in conjunction with its biological assessment. J Essent Oil-Bear Plants 17:277-287. https:// doi.org/10.1080/0972060X.2014.895161

Unlu M, Vardar-Unlu G, Vural N et al (2008) Composition and antimicrobial activity of Juniperus excelsa essential oil. Chem Nat Compd 44:129-131. https://doi.org/10.1007/ s10600-008-0040-x

Wedge DE, Tabanca N, Sampson BJ et al (2009) Antifungal and Insecticidal activity of two Juniperus essential oils. Nat Prod Commun 4:1934578X0900400. https://doi.org/10. 1177/1934578X0900400127

Weisbord SD, Soule JB, Kimmel PL (1997) Poison on lineacute renal failure caused by oil of Wormwood purchased through the Internet. N Engl J Med 337:825-827. https:// doi.org/10.1056/NEJM199709183371205

Wolf VC, Gassmann A, Clasen BM et al (2012) Genetic and chemical variation of Tanacetum vulgare in plants of native and invasive origin. Biol Control 61:240-245. https://doi.org/10.1016/j.biocontrol.2012.01.009

Xie Z, Kapteyn J, Gang DR (2008) A systems biology investigation of the MEP/terpenoid and shikimate/phenylpropanoid pathways points to multiple levels of metabolic control in sweet basil glandular trichomes. Plant $\mathrm{J}$ 54:349-361. https://doi.org/10.1111/j.1365-313X.2008. 03429. $x$

Yu H, Kosuna K, Haga M (1997) Perilla: the genus Perilla. CRC Press, Amsterdam

Zhao J, Zheng X, Newman RA et al (2013) Chemical composition and bioactivity of the essential oil of Artemisia anomala from China. J Essent Oil Res 25:520-525. https:// doi.org/10.1080/10412905.2013.820670

Zheljazkov VD, Astatkie T, Jeliazkova EA et al (2013) Distillation time alters essential oil yield, composition and antioxidant activity of female Juniperus scopulorum trees. J Essent Oil Res 25:62-69. https://doi.org/10.1080/ 10412905.2012.744704

Zhou Y, Liu JQ, Zhou ZH, Lv XT, Chen YQ, Sun LQ, Chen FX (2016) Enhancement of CD3AK cell proliferation and killing ability by $\alpha$-thujone. Int Immunopharmacol 30:57-61. https://doi.org/10.1016/j.intimp.2015.11. 027

Publisher's Note Springer Nature remains neutral with regard to jurisdictional claims in published maps and institutional affiliations. 